\title{
PARTY INSTITUTIONALISATION IN MOZAMBIQUE \\ 'The Party of the state' vs the Opposition
}

\section{Adriano Nuvunga and Eduardo Sitoe}

\author{
Adriano Nuvunga is a PhD student in the International Institute of Social \\ Studies, Erasmus University, Rotterdam, and lecturer in the Department \\ of Political Science and Public Administration, Eduardo Mondlane \\ University, Mozambique \\ e-mail: Adrianonuvunga@gmail.com
}
Eduardo Sitoe is Professor of Politics and Governance in the Department of Political Science and Public Administration, Eduardo Mondlane
University, Mozambique
e-mail: eduardo.sitoe@uem.mz

\begin{abstract}
The article probes party institutionalisation in Mozambique and argues that only three of the more than 50 registered political parties there are 'effective', namely Frelimo, which is highly institutionalised; Renamo, which is collapsing organisationally yet has a high level of social rootedness; and an institutionalising MDM. The article concludes that although the opposition parties are partly to blame for their misfortunes, the nature of Frelimo's relationship with society bears the main responsibility for the impoverishment of the opposition parties because it makes it difficult for opposition parties to break in and challenge its control over the state.
\end{abstract}

\section{INTRODUCTION}

There are few published studies on Mozambican political parties and those there are focus on elections. Studies of political parties have covered the following: the Frelimo party ideology (Brito 1988); building opposition (Manning 1998); strengths and weaknesses of multiparty democracy (Nuvunga 2005); the Frelimo-Renamo two-party system (Carbone 2005); the Renamo-UE coalition (Kadima \& Matsimbe 2006); The Movimento Democrático de Moçambique (Mozambique Democratic Movement - MDM) as a new force (Chichava 2010a) and the MDM as a new 
opposition party (Nuvunga \& Adalima 2011). With ‘Parties and Political Development in Mozambique, Sitoe, Matsimbe \& Pereira (2005) have, perhaps, done the most systematic study thus far of political parties in the country, but with a narrow focus on the Mozambique Liberation Front (Frelimo), Mozambique National Resistance (Renamo) and the Independent Party of Mozambique (Pimo).

This suggests little scholarly interest in political parties in Mozambique, which may not be anything new on the African continent as the overwhelming majority of post-independence African polities - that of Mozambique included - embraced the path of the one-party state. Scholarly interest in African political parties and party systems only resumed in the wake of the third wave of democratisation, early in the 1990s, as many African states lifted their bans on political activity, paving the way for the mushrooming of political parties. However, many of the early studies on the continent focused on the democratisation process itself (Mainwaring, O`Donnell \& Valenzuela 1992; Diamond 1994; Nwokedi 1995; Diamond \& Plattner 1999; Mohamed Salih 2001).

Nevertheless, back in the 1980s there were some systematic studies by Randall (1988) of Third World parties more generally and African political parties in particular. Randall's concern was demarcating and characterising Third World political parties and, importantly, she initiated a trend of studies on political party institutionalisation in this part of the globe. This trend was further developed by Randall \& Svåsand (2002); Mohamed Salih (2003) and Randall (2008). This article probes party institutionalisation in Mozambique, filling an important gap in the study of political parties and the party system in that country.

\section{METHODOLOGICAL APPROACH}

There are several scholarly definitions of political parties (Duverger 1985; Randall 1988; LaPalombara \& Weiner 1996; Moreira 2001; Heywood 2002; Smith 2009) but a more nuanced definition is found in Mohamed Salih (2003), who defines political parties as instruments of collective human action and creatures of political elites - either politicians trying to control governments or government elites trying to control the masses. Mohamed Salih's definition explicitly highlights the role of elites - which is essential for the present article and is possibly well placed to encapsulate the colourful realities of African politics.

Political parties are an integral part of party systems (Lindberg 2007), in other words, they are a central feature of pluralist polities. The implication is that the level of party institutionalisation matters most for the institutionalisation of party systems. While pointing out that institutionalised parties are not necessarily democratic - as this concept is more concerned with order and stability than democracy - Randall (2006) argues that party institutionalisation is key to the 
performance of citizen-related roles and to the provision of an effective opposition, the fundamental contribution parties can make to democratic consolidation.

In order better to understand party institutionalisation and its prospects in the African context it is worth starting by looking at the origins of parties. In principle, political parties reflect the historical circumstances that contributed to their emergence. In other words, the substance of political parties mirrors the social, economic and political relations in society (Smith 2009). For instance, whereas political parties in the West emerged from parliamentary institutions, suffrage, ideological movements, unions and churches as well as civil society and social movements (Duverger 1985), most parties in the African context were created by a small political elite to contest elections in preparation for independence or were formed soon after independence, when former liberation movements turned into political parties, and, more recently, in the context of constitutional reforms in the wake of the wave of democratisation in the 1990s (Mohamed Salih 2003).

Mohamed Salih (2003), however, claims that once founded and contesting elections African political parties have assimilated some of the institutional norms and behaviour of their Western counterparts. He points to the difference between the formalist and the substantive definition of the functions of political parties. The formalist definition allows for a generalisation of some universally assumed functions of political parties, whereas the substantive approach allows for the peculiarity of African political parties - as products of the socio-economic and political culture of their respective countries - to be teased out.

Scholarly literature (Randall 1988; LaPalombara \& Weiner 1996; Monga 1999; Moreira 2001; Randall \& Svåsand 2002; Heywood 2002; Mohamed Salih 2003) has summarised the following formalist functions of parties in a democratic polity: representation, conflict resolution, making government accountable, institutionalising democracy and lending legitimacy to the regime. This delineation of a party's functions corroborates the view that political parties are instrumental organisations for modern politics (Crotty 1993; Lipset 2000; Randall \& Svåsand 2002; Mohamed Salih 2003; Burnell 2004; Mozaffar \& Scarritt 2005; Kuenzi \& Lambright 2005), but, to be able to play such a role, they need to be institutionalised: firstly as organisations and secondly, in relation to society.

From a formalist viewpoint, however, African political parties are generally considered to be a weak link in the chain of elements that together make for a democratic state. Van de Walle \& Butler (1999) argue that African political parties are plagued by weak organisation and weak links with the society they are supposed to represent. Randall \& Svåsand (2002) take the argument further, arguing that this 'weakness' means that parties fail to contribute to the consolidation of democracy. 
Scholarly literature (Randall \& Svåsand 2002; Kopecký \& Mair 2003; Mohamed Salih 2003) presents several competing explanations for the weakness of African political parties. These include their dependence on direct or indirect government resources, poverty, a background of colonialism and political authoritarianism, the tiny African private sector, which is unable to support a strong and vibrant civil society that is autonomous of the state, control of the state's resources and personnel as a source of elite enrichment and parties as vehicles for the elite to access state resources.

Methodologically, the article is anchored in the concept of party institutionalisation. Randall (2006) notes that this concept has sometimes virtually been used as a synonym for 'organised'. She asserts, however, that organisations are not necessarily institutions, although they may institutionalise over time, and institutions can have organisational aspects and develop within organisational contexts. Huntington (1968) originated the concept as the process whereby organisations and procedures acquire value and stability. Randall \& Svåsand (2002), who have provided the most sophisticated theoretical discussion of party institutionalisation, have defined it as 'the process by which the party becomes established in terms of both integrated patterns of behaviour and attitudes, or culture' (p 3).

Randall \& Svåsand (2002) suggest the need to distinguish between internal and external aspects of this process. Internal aspects refer to developments within the party itself and external aspects refer to the party's relationship with the society in which it is embedded, including other institutions. They make it clear that party institutionalisation is a complex process and that different dimensions of institutionalisation might not be developing simultaneously or to the same extent. Building on Randall \& Svåsand (2002), Basedau \& Stroh (2008), who define party institutionalisation as a process in which individual political parties that participate in elections experience rising organisational stability and value, have developed an index for measuring party institutionalisation.

The above definition offers good criteria for selecting the sample, as it explicitly limits the concept to the parties contesting elections. The article borrows from the framework of the Index of Institutionalisation of Parties (IIP) to qualitatively assess party institutionalisation in Mozambique. The IIP is an insightful framework on which to build the narrative of party institutionalisation, in a context of democratisation, as it puts parties at the crossroads of the political and social spheres in society while probing critical organisational aspects of political parties and therefore offering a substantive account of the landscape of political parties as integral parts of party systems. 


\section{Table 1}

Dimensions of Party Institutionalisation

\begin{tabular}{|l|l|l|}
\hline & Stability & Value-infusion \\
\hline External & Roots in society & Autonomy \\
\hline Internal & Level of organisation & Coherence \\
\hline
\end{tabular}

Source: Basedau \& Stroh 2008, p 9

For each of the IIP sub-indices, that is, roots in society, autonomy, organisational level and coherence, there are specific questions to be addressed (see Table 2). Recognising that party institutionalisation is a complex process in which different dimensions of institutionalisation might not be developing simultaneously, and also taking into consideration that Mozambique's multiparty system is only 20 year old, the authors focus more on the 'stability' dimension of party institutionalisation both internally (level of organisation) and externally (roots in society), with the 'level of organisation' carrying the greater weight in relation to the conclusions presented in the article. In the context of an embryonic democratic culture, of widespread illiteracy in rural areas where most people live and widespread political intimidation in electoral epochs, it is of significant political importance that opposition parties are at least able to achieve meaningful levels of organisation and perform some political and electoral activities.

Table 2

Dimensions and Indicators of the Index of Party Institutionalisation

\begin{tabular}{|l|l|}
\hline \multirow{3}{*}{ Roots in society } & Indicators \\
\cline { 2 - 3 } & Party age relative to independence \\
\cline { 2 - 3 } & Party age relative to the start of the multiparty period \\
\cline { 2 - 3 } & Changes in electoral support between last and second ${ }^{1}$ elections \\
\cline { 2 - 3 } & Links to civil society organisations \\
\hline \multirow{3}{*}{ Autonomy } & Number of alternations in party leadership \\
\cline { 2 - 2 } & Changes in electoral support after alternation in party leadership \\
\cline { 2 - 3 } & Decision-making autonomy from individuals and groups \\
\cline { 2 - 2 } & Popular appreciation of a particular party \\
\hline
\end{tabular}




\begin{tabular}{|l|l|}
\hline \multirow{5}{*}{ Organisation } & Membership strength \\
\cline { 2 - 2 } & Regular party congresses \\
\cline { 2 - 2 } & Material and personal resources \\
\cline { 2 - 2 } & $\begin{array}{l}\text { Nationwide organisational presence, activities beyond electoral } \\
\text { campaigns }\end{array}$ \\
\hline \multirow{2}{*}{ Coherence } & Coherence of parliamentary group (no defections or floor crossing) \\
\cline { 2 - 3 } & $\begin{array}{l}\text { Moderate relations between inter-party groupings (no dysfunctional } \\
\text { factionalism) }\end{array}$ \\
\cline { 2 - 2 } & Tolerance vis-à-vis intra-party dissidence \\
\hline
\end{tabular}

Source: Basedau \& Stroh 2008

The political landscape in Mozambique is dominated by Frelimo and Renamo, both of which have military origins. Apart from these two, the landscape is also home to dozens of parties with no such origins. By 1994, the year of the democracyfounding elections, there were only 10 officially registered parties, with the number increasing to 26 just before the second general elections, held in September 1999. Today there are about 50 . Using the definition of 'effective parties' used by Sartori (1976), that is, main parties as well as those with coalition leverage, or the Index of the Effective Number of Parties (N) devised by Laakso \& Taagepera (1979), which focuses on seat share, this article focuses on the 'relevant' parties, those with seats in Parliament, namely Frelimo, ${ }^{1}$ the former rebel movement, Renamo, and the party that broke away from Renamo, the MDM.

\section{Table 3}

Distribution of Parliamentary Seats in the 1994, 1999, 2004 and 2009 Elections

\begin{tabular}{|l|r|r|r|c|}
\hline Party & $\mathbf{1 9 9 4}$ & $\mathbf{1 9 9 9}$ & $\mathbf{2 0 0 4}$ & $\mathbf{2 0 0 9}$ \\
\hline Frelimo & 129 & 133 & 160 & 191 \\
\hline Renamo & 112 & 117 & 90 & 51 \\
\hline UD & 9 & 0.0 & - & - \\
\hline MDM & - & - & - & 8 \\
\hline
\end{tabular}

Source: Author's compilation from official results published by CNE/STAE

1 In parts of this article the name Frelimo is written in upper and in other parts in lower case. This differentiates between FRELIMO (the acronym of the Frente de Libertação de Moçambique, the broad movement that led the armed national liberation struggle) and Frelimo (the name of the political party resulting from the transformation of FRELIMO in 1977, two years after independence). 
Table 3 highlights Frelimo's dominance. ${ }^{2}$ When analysing party systems in Africa scholarly literature has documented a trend towards declining political competitiveness and the entrenchment of ruling parties and presidents (Van de Walle \& Butler 1999; Bogaards 2000; 2004; Sanches 2010) with the parties that ushered in independence and / or the former one-party state enjoying prolonged periods in government to the point of becoming the parties of government. Van de Walle \& Butler (1999); Bogaards (2000; 2004); Mohamed Salih (2003); Kuenzi \& Lambright (2005); Manning (2005); Mozaffar \& Scarrit (2005) and Carbone (2007) have reached similar conclusions that 'the spread of multi-party politics in the 1990s has given rise to dominant parties' (Bogaards 2004, p 173).

As the above picture mirrors the reality in Mozambique - and assuming that party dominance entails many of the aspects of party institutionalisation - this article will first analyse Frelimo's relationship with society and then examine the impact of that relationship on the prospects for the institutionalisation of (the opposition) political parties. The article is based mainly on qualitative research. In-depth semi-structured interviews were conducted with key informants, that is, political and civil society actors; party leaders and party officials, from national to district branches.

\section{FRELIMO-SOCIETY RELATIONSHIP}

One of the longest-serving political parties in Africa, the Mozambique Liberation Front (FRELIMO) was founded in Dar-es-Salaam, Tanzania, in 1962, when three regionally based nationalist movements: the Mozambican African National Union (Manu) ${ }^{3}$, the National Democratic Union of Mozambique (Udenamo) ${ }^{4}$

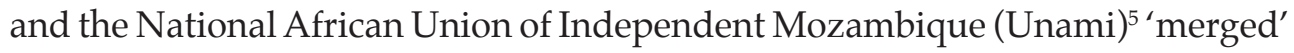
into one broad-based guerrilla movement. Brito (2009) and Sitoe (forthcoming) question the idea of 'unification' of these three pre-existing movements to refer to the foundation of FRELIMO on the grounds that their leaders subsequently

2 A ruling party overcomes the dominance threshold when it wins more than $60 \%$ of the vote in two consecutive elections (Van de Walle \& Butler 1999).

3 Manu, whose leaders were Mateus Mole and Malinga Milingo, was a movement formed essentially by Makonde migrants in Kenya and Tanzania.

4 Udenamo's founders were Mozambican emigrants in the former Southern Rhodesia, most of whom were from the former colonial district of Manica and Sofala, apart from its president, Adelino Gwambe, who was born in Inhambane, Southern Mozambique and worked in Beira, the old capital of Manica and Sofala district before emigrating to Southern Rhodesia.

5 Unami, led by Baltazar da Costa Changonga from the then district of Tete, was formed in 1961 mainly by natives of the same district. 
abandoned FRELIMO ${ }^{6}$ and attempted to re-launch their former organisations, with differing degrees of success.

Later, another wave of desertions hit FRELIMO when a sizeable number of key leaders abandoned the liberation movement following deep political and ideological confrontations within the FRELIMO leadership in the mid-1960s. This paved the way for the formation of a hegemonic bloc at the helm of FRELIMO, fairly cohesive, firmly bound together and somehow immune to outside influence (Sitoe forthcoming). So, although throughout the transitional government from the Lusaka Agreement in September 1974 to Mozambique's independence in 1975 other political groups appeared ${ }^{7}$ intent on participating in the national independence process, they were banned and independence was proclaimed on 25 June 1975, leaving FRELIMO as the only representative of the Mozambican people (Serra 1993; Jossias 2007; Brito 2009).

As was the case with liberation movements in the other Lusophone African countries, the liberation struggle, and later the proclamation of independence, gave FRELIMO a source of legitimacy to claim the leadership of the country and its political project of state construction and modernisation as a Socialist People's Republic (Lundin 1995; Brito 1988, 2009; Sitoe 2004; Carbone 2005; Sitoe 2011). This Estado Novo (new state) was depicted by the historian Newitt (1995) as having epitomised an unquestionable power over the masses and as acting according to its own reasoning. The 'state's reason' and its representatives, institutions, symbols, public holidays and so on, were portrayed as virtually sacred.

Defined as the vanguard of the revolution, initially FRELIMO, and later Frelimo, created and ran a constitutional one-party socialist state from 1975 to 1990, banning the formation and activity of political parties. Frelimo's leading role in society was shaped by its victory in the 10-year liberation struggle and particularly by the proclamation of independence in 1975 (Lundin 1995; Brito 1988; Sitoe 2004; Carbone 2005; Brito 2009). In other words, it was moulded, on the one hand, in the context of liberating the 'land' and 'the people' from colonial rule and on the other, by the nature of the post-independence state subordinated

6 Eduardo Mondlane, a Changana from Manjacaze in Gaza province, Southern Mozambique, was elected president of FRELIMO and Uria Simango, vice-president. FRELIMO experienced internal tensions along tribal and regional divides, with people from the Central and Northern provinces alleging southerntribe-based exclusion. Following tensions and expulsions from the movement a separatist movement was formed in 1968: the National Union of Rombézia (UNAR). According its leaders - who sought independence for the region from the Rovuma to the Zambezi (Cabo Delgado, Niassa, Nampula, Tete and Zambézia) - the southern leaders of FRELIMO were using the northerners as 'cannon fodder' - keeping themselves in offices or going abroad to study - while waging the war only in Northern Mozambique, harshly punishing the people of this region (Chichava 2010b).

7 Grupo Unido de Moçambique (Gumo), Comité Revolucionário de Moçambique (Coremo) as well as others that existed underground during the fight for independence (Adalima 2009). 
to Frelimo as the vanguard of the revolution. Substantively, Frelimo's ideological programme, which aimed to provide social justice, basic services (education and health) and political and social equality without any ethnic, religious or racial discrimination was the justification for controlling the masses.

However, almost two years after independence Renamo appeared as a rebel movement, initially backed by the Rhodesian regime then, after Zimbabwe's independence in 1980, much more vigorously by the South African apartheid regime. Although it did not collapse the state, the 16-year civil war created a crisis in the relationship between Frelimo and society as it challenged the leading role claimed by Frelimo in relation to the masses. Frelimo had to negotiate with the rebel movement. First, in March 1984, Frelimo negotiated and signed an agreement, the Nkomati Accord, with the South African regime. In terms of the agreement South Africa would stop providing material support to Renamo in exchange for the Mozambican government's neutrality in relation to the African National Congress (Mazula 1995).

The Nkomati Accord reflected Frelimo's difficulty in recognising the rebel movement as a relevant participant in the Mozambican political process, not just an instrument of externally-supported political and economic destabilisation (Mazula 1995). However, as the war continued there had to be negotiations between the warring parties and these led to the 1992 General Peace Agreement. Before this, however, Frelimo promulgated the 1990 Constitution that inaugurated the democratisation of the country (that is, lifted the ban on political parties) and provided for freedom of the press and freedom of association. The Constitution gave Frelimo priority over the other parties with a statement in its preamble that democracy should not jeopardise national unity and that Frelimo, which had fought for national independence and 'brought together all patriotic sectors of Mozambican society in a single ideal of liberty, unity, justice and progress' (Article 31), was the guarantor of this national unity.

As Mazula (1995, p 350) writes, this 'implied that the unitary state and the country's sovereignty corresponded to hegemony by the Frelimo party'.

Frelimo wanted to end the war, while, at the same time, defending the political and state power it had been consolidating since independence. This had been the main tone of the Fifth Frelimo Congress, held in 1989, which had proposed amnesty for Renamo guerrillas and suggested that they be integrated into the state machinery. Renamo, in turn, needed official government recognition. The government recognised Renamo as an important actor in the Mozambican political process and signed with it the General Peace Agreement (Acordo Geral de Paz-AGP). Before this, however, it had skilfully established democratisation 
from above, ${ }^{8}$ giving Frelimo the privilege of remaining in power ${ }^{9}$ and thus implementing the various protocols that included Renamo's integration into society and its transformation into a political party.

Renamo controlled 25\% of the country (Mozambique Political Process Bulletin $1 \& 2$ 2003) and claimed the fatherhood of democracy and this had an impact on the relationship between Frelimo and society: firstly, Frelimo had to admit to the existence of other political groups; secondly, it had to compete with these groups, of course, trying to impose itself as the legitimate political group to lead the country and, thirdly, it had to direct part of its capacity to thwarting Renamo's ascendency. This context shaped Frelimo's politics and its relationship with society in the subsequent 20 years of democratisation in Mozambique.

It did this by undermining the political importance of the General Peace Agreement (AGP), subjecting it to the approval of the then (single-party) People's Assembly and subsequent promulgation by the president of the republic, who was also a signatory to the AGP. This not only enabled Frelimo to position itself above Renamo with regard to the AGP but also to interpret multiparty politics as its own initiative (emanating from the 1990 Constitution), so the parties, mainly Renamo, had to conform to it.

Frelimo's victory in the 1994 democracy-founding elections gave it the privilege of not only using history (Brito 2009) but also of re-writing and appropriating the history of the liberation struggle as its own. So the FRELIMO (liberation movement) founding myths, its heroes and symbols were not only appropriated by Frelimo (political party) but were also made those of the state. Since 1994 Frelimo has not only successfully removed Renamo from the 25\% of territory it controlled in 1992 but has also worked to thwart Renamo's links with its strongholds. For example, traditional authorities were abolished soon after independence and throughout the civil war they sided with the former rebel movement and supported Renamo in the 1994 and 1999 general elections. So, from 2000 onwards, Decree 15/2000 integrated them into local politicaladministrative structures together with local Frelimo party representatives, thus manipulating and co-opting them into the political and administrative system (Forquilha 2006; Forquilha \& Orre 2012). Another example is the removal and destruction, apparently by the Frelimo administrative machine, of opposition

8 The distinctive feature of democratisation from above is that an authoritarian regime or military dictatorship undertakes the democratisation process, albeit under pressure from its opponents in civil society. The emphasis is normally on the reform of the constitution and the existing institutions of government through the normal reform process; the opposition may or may not provide input for the reform (Nwokedi 1995).

9 In a meeting in Gaborone on 4 July 1992, preceding the signing of the AGP, Renamo president Afonso Dlhakama, stated that he accepted that the current Frelimo government would remain in power until the 1994 elections (Della Rocca 1998). 
party flags, particularly those belonging to Renamo and the Mozambique Democratic Movement.

Independent media speak of a de facto rather than a de jure one-party state or a scenario of a state captured by Frelimo. Its Tenth Congress, in September 2012 in Cabo Delgado, was the ultimate demonstration of state institutions in the service of Frelimo. In this connection Joseph Hanlon (2012) described Frelimo as 'the party of the state', referring to the fact that $57 \%$ of the 2000 delegates at that congress were state employees. Moreover, one of the key party founders and ideologists, Marcelino dos Santos, made a telling statement about Frelimo-society relations when he said 'the history of Mozambique is Frelimo's history' (Noticas 19 June 2007) and that 'whoever stands in an election on the Frelimo ticket will be elected' (STV May 2005). These statements reveal Frelimo's claim to 'own' Mozambique's history and society.

Frelimo's relations with society were also shaped by the 1987 introduction of a structural adjustment programme at the behest of the Bretton Woods institutions. This initially represented a crisis within the party and its relations with society as it meant a major paradigm shift (from socialism to a market economy, previously considered an arm of imperialism in post-independence Mozambique). Frelimo leaders grabbed at the opportunity to build a political economy (institutions, policies, incentives and resources) that it could not only use to its advantage but which would also inhibit other political groups from entering the economy.

Frelimo implemented economic liberalisation and a politically controlled privatisation at a time when the rebel movement was busy fighting the regime. So the Frelimo elite found that they could not only transform the socio-economic base of the state but also benefit from privatisation by taking over former state companies as born-again entrepreneurs (Pitcher 1996; Bowen 1992; Sumich \& Honwana 2007; African Peer Review Mechanism - MARP - 2010). They assumed that society would accept this as it was they who had liberated 'land' and 'man'.

Frelimo-society relations also have their seeds in civil society. Interest and pressure groups are free to register and agitate, but there is widespread Frelimo control (MARP 2010). Several interviewees were unanimous in saying that it took courage to establish and run an independent civil society organisation. To counteract critically vocal civil society organisations Frelimo either sets up organisations with a similar name ${ }^{10}$ to confuse the public, or disqualifies the leaders of these organisations, stating that they are serving foreign interests. Interviews in three provinces, namely Zambézia, Inhambane and Gaza, revealed that critically

10 The Association for Human Rights and Development (DHD) was established so people would confuse it with the vocally critical Human Rights League (LDH) (Guiliche 2011); similarly, the Parliamentary Youth Office (Gabinete Parlamentar da Juventude) may be confused with the Youth Parliament (Parliament Juvenil). 
vocal organisations outside the capital, Maputo, cannot survive political control '...one has to be careful with words', say Carlos Mula and Armando Guambe, civil society leaders in Gaza. While Frelimo virtually banned religion after independence, today its leaders participate in the events of all churches and church leaders are co-opted for several state missions, mainly the electoral administration.

In conclusion, Frelimo's relationship with society is shaped by its victory in the 10-year liberation struggle and, in particular, by the proclamation of independence in 1975. It has been moulded in the context of liberating the 'land' and the 'people' from colonial rule; by commanding the heights of the political economy produced by economic liberalisation and a politically controlled privatisation; by the re-writing and privatisation of the liberation struggle; by thwarting the ascendency of the opposition, mainly Renamo, but more recently the MDM. All in all, Frelimo has problems accepting that other political groups can mobilise support among the people in the land it liberated from colonial rule.

\section{THE LANDSCAPE OF OPPOSITION PARTIES IN MOZAMBIQUE}

The notion of 'political party' is novel in Mozambique. It entered the political vocabulary only in 1977 when FRELIMO transformed itself into a political party two years after independence. After the political abertura $a^{11}$ and the 1990 Constitution, which lifted the ban on political activity, dozens of non-armed parties emerged. They were dubbed emerging or non-armed opposition political parties, to distinguish them from the rebel movement, Renamo, which became a political party in 1993 in the context of the 1992 General Peace Agreement (Nuvunga 2005).

Interestingly, the most outspoken parties that emerged between the introduction of the Constitution in 1990 and the first multiparty election in 1994 were formed by or linked to personalities who had either deserted or were expelled from FRELIMO before independence. They included the Mozambique Nationalist Movement (Monamo) ${ }^{12}$, the Mozambique United Front (Fumo) $)^{13}$, the

11 A Portuguese term that has entered comparative political discourse as a description of Brazil’s gradual transition from military to elected government (Joseph 1999).

12 Monamo was founded by Maximo Dias in the then Rhodesia in 1979. Before returning to Mozambique after the approval of the Constitution in 1990 Dias lived in Portugal for many years.

13 Fumo was founded by Domingos Arouca, a lawyer arrested by the Portuguese colonial authorities in the 1960s for allegedly having radio contact with FRELIMO in Tanzania. He went into exile in Portugal and said he formed Fumo in 1976. He dropped out for health reasons in 1980 (Mozambique Peace Process Bulletin October 1993). 
National Democratic Party (Panade) $)^{14}$ and the National Convention Party $(\mathrm{PCN})^{15}$. Monamo and Fumo were also linked to political groups that appeared throughout the transitional government that preceded Mozambique's independence.

The remaining parties were formed by individuals who deserted Frelimo in the 1980s for various reasons (Table 4), including marginalisation and / or failure to progress in the hierarchy (Sitoe, Matsimbe \& Pereira 2005); parties formed by leaders who split from Renamo during the civil war (Unamo/Udemo); parties resulting from breakaways ${ }^{16}$ within the newly formed non-armed opposition parties (Table 5) and parties set up by political entrepreneurs pursuing individual fortunes or increased personal prestige in the run-up to the 1994 elections and mainly motivated by the financial support provided by the 1994 UN Trust Fund to support parties and candidates contesting national elections ${ }^{17}$ (Table 6). There has also been a strong trend towards coalitions in party structuring activity.

14 Panade was founded by Jose Massinga, who had been a member of Frelimo during the independence war but became a dissident while studying abroad. He returned to Mozambique soon after independence and was appointed director of research and personnel in the Ministry of Foreign Affairs but was arrested in a crackdown on alleged CIA operations and, at an international news conference in Maputo in 1981, confessed to having been recruited by the CIA in 1975. He was never publicly tried but spent some years in jail before receiving amnesty and going into exile again (Mozambique Peace Process Bulletin October 1993).

15 The PCN was formed by a group of intellectuals (Vasco Campira, Inacio Chire, Abel Mabunda, Bernabe Nkomo) including Lutero and Deviz Simango, the sons of Uria Simango, who was FRELIMO's vicepresident in the 1960s, was disgraced and expelled in 1970, arrested just before independence in 1975 and secretly executed some years later (Nuvunga \& Adalima 2011). The abbreviation PCN was first used by Uriah Simango for a party he created in 1974 after the overthrow of Marcelo Caetano in Portugal and which was essentially challenged by the Lusaka Accord, which recognised and legitimised Frelimo as the only representative of the Mozambican people (Lundin 1995; Chichava 2010 b).

16 A breakaway group or party can be defined as one where, due to irreconcilable differences among the party's leaders and some of its officials or members, the latter decide to resign and form another group or party. In many instances those perceived to be a threat to party leadership are purged, forcing them to form parties of their own to settle old scores. However, the circumstances that lead to breakaway groups can often be found in the nature of the African parties themselves, in particular the entrenched authoritarian and undemocratic tendencies of most parties in the region (Simutanyi 2009, p 6).

17 As part of the peace process the United Nations Operations for Mozambique (Onumoz) established a Trust Fund to support the non-armed parties and candidates contesting the first multiparty elections. The trust provided about US\$3.5-million, a little over US\$200 000 for each of the 17 parties involved (Nuvunga 2007). 
Table 4

Parties formed by leaders who deserted Frelimo in the 1980s

\begin{tabular}{|l|l|}
\hline Party name & Founders/history \\
\hline $\begin{array}{l}\text { Mozambique People's Progress Party } \\
(\text { PPPM })\end{array}$ & Padimbe Kamate, exiled in Lisbon \\
\hline Mozambique Democratic Party (Pademo) & $\begin{array}{l}\text { Wehia Ripua, a Frelimo commander during } \\
\text { the liberation struggle in the 1960s }\end{array}$ \\
\hline Mozambique Liberal Party (Palmo) & $\begin{array}{l}\text { Martins Bilal, a Frelimo commander in the } \\
1960 s\end{array}$ \\
\hline
\end{tabular}

Source: Authors' compilation

Table 5

Parties formed as breakaways within the non-armed opposition

\begin{tabular}{|l|l|}
\hline Party name & Founders/history \\
\hline Social-Liberal Democratic Party (SOL) & $\begin{array}{l}\text { Casimiro Nyamitambo, a breakaway from } \\
\text { Palmo }\end{array}$ \\
\hline Democratic Congress Party (Pacode) & $\begin{array}{l}\text { Vasco Campiro Momboya, a breakaway } \\
\text { from the PCN }\end{array}$ \\
\hline $\begin{array}{l}\text { Nationalist Federalist Party (Panafe, later } \\
\text { Panamo) }\end{array}$ & Marcos Juma, a breakaway from Pademo \\
\hline Mozambique National Union (Unamo) & $\begin{array}{l}\text { Initiated by Gimo Phiri, a former Renamo } \\
\text { commander, who broke away in 1986. He } \\
\text { disagreed with Carlos Reis and left the } \\
\text { party, which Reis took over. }\end{array}$ \\
\hline Mozambique Democratic Union (Udemo) & $\begin{array}{l}\text { Gimo Phiri founded Udemo in April 1992 as } \\
\text { a breakaway from Unamo }\end{array}$ \\
\hline Labour Party (PT) & $\begin{array}{l}\text { Miguel Mabote, a breakaway from Padimbe } \\
\text { Kamati's Mozambique People's Progress } \\
\text { Party (PPPM) }\end{array}$ \\
\hline
\end{tabular}

Source: Authors' compilation 


\section{Table 6}

\section{Parties formed by political entrepreneurs in pursuit of personal fortunes}

\begin{tabular}{|l|l|}
\hline Party name & Founders/history \\
\hline Patriotic Action Front (FAP) & $\begin{array}{l}\text { Jose Palaço. Founded in February } 1991 \text { by } \\
\text { students and former students of Eduardo } \\
\text { Mondlane University }\end{array}$ \\
\hline $\begin{array}{l}\text { Mozambique Independent Congress } \\
\text { (Coinmo) }\end{array}$ & $\begin{array}{l}\text { Victor Marcos Saene. Coinmo became the } \\
\text { second opposition party to hold its founding } \\
\text { congress inside the country, but there were only } \\
\text { five delegates plus Saene's wife and the man in } \\
\text { whose house the couple was living. }\end{array}$ \\
\hline $\begin{array}{l}\text { Mozambique Independent Party } \\
\text { (Pimo) }\end{array}$ & $\begin{array}{l}\text { Yaqub Sibindy. Claims to be a former soldier } \\
\text { and his deputy claims to be a Renamo dissident }\end{array}$ \\
\hline $\begin{array}{l}\text { Chiefs and Peasants of Mozambique } \\
\text { (Recamo) }\end{array}$ & $\begin{array}{l}\text { Arone Fijamo in Zambézia province. Fijamo } \\
\text { wants to restore traditional authority. }\end{array}$ \\
\hline $\begin{array}{l}\text { Liberal Federal Progressive Party of } \\
\text { (PPLFCRM, later PPLM) }\end{array}$ & $\begin{array}{l}\text { Neves Serrano. He claims he previously held a } \\
\text { senior post in the Criminal Investigation Police }\end{array}$ \\
\hline $\begin{array}{l}\text { Democratic Party for the Liberation of } \\
\text { Mozambique }\end{array}$ & Joaquim Jose Nyota \\
\hline $\begin{array}{l}\text { Mozambique Federal party (Pafemo) } \\
\text { Manuel Palange and President Mariano Janeiro } \\
\text { Pordina. They claimed to have had an army, the } \\
\text { Mozambican Federal Army, (Exefemo), in 1991, } \\
\text { although it has never been seen. }\end{array}$ \\
\hline
\end{tabular}

Source: Authors' compilation

Ministry of Justice records suggest that there are more than 50 registered political parties but the reality of party activity is very different. As it stands, the mapping of the non-armed opposition parties suggests five major trends:

- Parties that faded away after the death of their founders. ${ }^{18}$

- 'Suitcase parties' that retired altogether with their founders. ${ }^{19}$

- Parties that disappeared after merging with other parties. ${ }^{20}$

18 Mozambique National Union (Unamo); Mozambique United Front (Fumo); Mozambique Democratic Party (Pademo), Mozambican People's Progress Party (PPPM); Social-Liberal Party (SOL).

19 The most notable are the Democratic Liberal Party of Mozambique (Padelimo); United Congress of Democrats (CDU); Party for Liberal Progress of Mozambique (PPLM); Mozambique Nationalist Movement (Monamo).

20 The PCN did not formally merge but its founding leaders left the party moribund and joined the MDM. 
- Parties that succumbed to/ or were co-opted by Frelimo, particularly after the 2009 general elections, with some of their leaders being granted positions as board members in public companies. ${ }^{21}$

- Party breakaways that gave birth to parties with substantial mobilisation capacity. ${ }^{22}$

At present, there are no reliable data on how many non-armed opposition parties are still in existence, but realistically very few meet the minimum criteria for a political party.

With the exception of Frelimo, Renamo and the MDM, the Labour Party (PT) is the most consistent as it has contested all four legislative elections to date, but with inconsequential electoral support. It is followed by Pimo and SOL, with three elections each, and Padelimo, PAZS, PVM, Parena, PDD, Palmo, Panaoc and PECMT, with two elections each, all with negligible electoral support. The electoral landscape shows that none of the political parties established between 1990 and 1994 made it to the second and third general elections. Although most had articulate leaders they were no more than platforms for political elites-mainly returning to the country from exile after it opened up politically - to participate in the political arena. Most of these elites established their parties to resolve past grievances relating to their expulsion from or marginalisation within FRELIMO/ Frelimo, thus the parties did not outlast their founders.

In the early 1990s most of the non-armed opposition parties appeared to have nationwide coverage, as their leaders could move quickly across the country, but in reality they were only based in Maputo. Over time, and without any kind of financial support, the non-effective parties, with the exception of the PDD and Panade, closed their offices. They exist mainly as virtual organisations expressed in the person of the leader. Party leaders confirmed that the addresses they provide are their own homes in the outlying neighbourhoods of Maputo City.

With the exception of Pasomo, the Ecologist Party, UDF, Parede, PSDM and PLDM, which have supported the newly formed MDM, the overwhelming majority of non-effective parties have succumbed to co-option by Frelimo (Nuvunga \& Mohamed Salih 2010).

Following their exclusion from the 2009 legislative elections the PT, PIMO, Parena, Panamo, MPD, ADACD, SOL and PECMT declared their unconditional support for Frelimo and its presidential candidate, Armando Guebuza. In both

21 The most visible are the following: the Independent Party of Mozambique (Pimo); Labour Party (PT); Ecological Party-Land Movement (PECMT) and the Mozambique Nationalist Party (Panamo).

22 The Party for Peace, Democracy and Development (PDD) and the Mozambique Democratic Movement (MDM), both breakaways from Renamo. 
cases, however, this support was essentially symbolic, as they are tiny parties with an inconsequential share of the vote (Nuvunga \& Mohamed Salih 2010). For instance, in the 2004 general election, the PT won $0.47 \%$ of the parliamentary vote and the Ecologist Party did even worse, with $0.4 \%$.

In 2007 the PT, Pimo, Parena, Panamo, MPD, ADACD, SOL and PECMT established the Constructive Opposition Bloc. Although the concept of a 'loyal opposition' is not novel to parliamentary systems, the Constructive Opposition Bloc is an odd Mozambican innovation. Since it was established, its leaders, Pimo's Yaqub Sibindy, ${ }^{23}$ the PT's Miguel Mabote ${ }^{24}$ and PEC-MT's João Massango ${ }^{25}$ have been frequent guests at presidential banquets and important invitees to official state and Frelimo events, including the Tenth Frelimo Congress held in September 2012. In 2006 Pimo made a public financial contribution to the Ninth Frelimo Congress but two years later the party was evicted from its offices for non-payment of rent. With tickets provided by the Ministry of Foreign Affairs leaders of the Constructive Opposition Bloc toured Zimbabwe, Malawi, Zambia, China, Brazil and Sweden to explain their new model of party activity.

Overall, of the non-effective parties only the PDD conforms to our concept of a political party. It was formed in 2004 as a breakaway from Renamo by Raul Domingos, who had headed the Renamo delegation to the peace negotiations in Rome and also the Renamo parliamentary group in the first multiparty Parliament. The PDD appeared on the national political chessboard displaying capacity and resources that are rare among opposition parties. It was luxuriously put together throughout the country, rivalled the two main parties and had the advantage of a leader with political management experience. Over time, however, it became clear that it was merely an instrument for its leader to attain power. Unfortunately, its electoral failure in 2004 and the drying up of its funds withered the party's dynamics and it is now reduced to its leader.

\section{ANALYTICAL NARRATIVE OF PARTY INSTITUTIONALISATION}

Using the concept of 'effective parties' defined by Sartori (1976), or the Index of Effective Number of Parties (N) devised by Laakso \& Taagepera (1979), which focuses on the share of seats, this section looks at the 'relevant' parties, that is, those with seats in Parliament. The parties are Frelimo, Renamo and the Renamo breakaway, the MDM. With reference to the IIP framework, these parties are

23 Yaqub Sibindy was made a member of the National Commission for Honorary Titles and Decorations and is on the payroll of the Ministry of Foreign Affairs as an adviser to the minister.

24 Miguel Mabote, the leader of PT, was made a member of the board of the Maputo Transport Company (TPM) and confirmed his allegiance to Frelimo in an interview with TVM on 4 October 2012.

25 João Massango, the leader of PEC-MT, was appointed to the board of STEMA, a public company. 
analysed in both their internal ('level of organisation' and 'coherence') and external ('roots in society' and 'autonomy') dimensions of institutionalisation in light of the relations between Frelimo and society. This section uses the data from the interviews to analyse the three parties according to the various sub-indicators in each of the four dimensions of party institutionalisation.

\section{Roots in society}

Frelimo is the oldest party in the country. It was formed in 1977 as a result of the transformation of the former liberation movement - FRELIMO - into a political party. Renamo is the former rebel movement that began fighting the Frelimo government a few years after independence in 1975 and is the second-oldest party. The MDM, formed in 2009, is the newest party. Although formally it is a Renamo breakaway party, the MDM is also linked to the Partido de Convenção Nacional (National Convention Party - PCN) ${ }^{26}$ founded in 1992 by young intellectuals, including Lutero Simango, one of Uria Simango's sons. Formally, only Frelimo existed prior to the multiparty system but Renamo also existed substantively at that time and transformed itself into a political party to contest the democratic elections. The MDM only appeared on the eve of the country's fourth general elections, held in 2009.

\section{Figure 1}

\section{Percentage of Voter Share of Effective Parties}

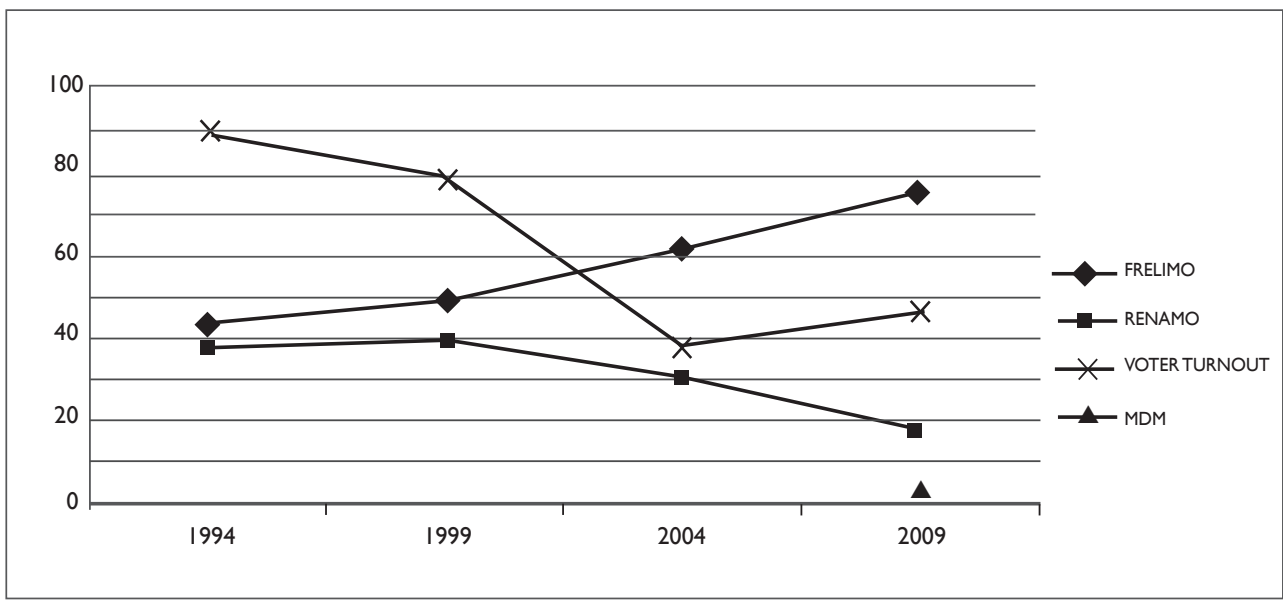

26 The abbreviation PCN was first used by Uriah Simango for a party he created in 1974 after the overthrow of Marcelo Caetano in Portugal. It was challenged by the Lusaka Agreement, which recognised and legitimised Frelimo as the only representative of the Mozambican people (Lundin 1995; Chichava, 2010 b). 
In the context of a declining voter turnout, Figure 1 shows a failing Renamo, while Frelimo not only managed to maintain but actually increased its electoral support. Frelimo claims to have three million members, which is consistent with its average electoral support in the four elections to date. However, there have been procedural irregularities, including ballot box stuffing, orchestrated by Frelimo groups in all elections except the first democratic elections in 1994 (Nuvunga \& Mohamed Salih 2010).

Senior Frelimo figures have acknowledged the difficulty of mobilising all the party's members and supporters to vote. For instance, in the 2011 by-election in Quelimane Frelimo won only 13000 votes despite its claim to have 40000 members in the town '... just because people felt obliged to join the party and as such they do not vote ... so there are many people in the party who are not of the party' ${ }^{27}$

As the former single party Frelimo has influence in almost all spheres of society, from the private sector and businesses (Nuvunga \& Hout forthcoming) to segments of civil society organisations. Elsewhere in this article it is argued that Frelimo is creating civil society organisations (Rønning 2010) and that in some cases it co-opts leaders of civil society organisations by giving them positions in government (Guiliche 2011). There are also, however, cases of leaders who use civil society organisations as platforms to project themselves publicly in order to achieve space within Frelimo.

At the time of the 1994 and 1999 elections Renamo not only still controlled parts of the national territory it also had alliances with traditional authorities and so had a substantial electoral support base. However, with the government's use of Decree 15/ 200 to co-opt traditional authorities (Forquilha 2009; Forquilha \& Orre 2012) and the arrival of Armando Guebuza as the president of Frelimo and his revitalisation of the party's grass roots, much of Renamo's political and electoral support base fell away (Brito 2009).

When it emerged from the bush in 1992 after the General Peace Agreement, Renamo distrusted all cities, and Maputo, the capital, in particular, because they were allegedly Frelimo strongholds (Manning 1998; Nuvunga 2005; Carbone 2005). The distrust between Renamo and Frelimo was such that Renamo was unable to establish constructive relations with civil society groups. 'Renamo always behaved like an organisation under siege,' says João Ulrich, director of an international organisation that worked closely with Renamo for many years.

While Renamo is correct in saying that Frelimo exercises influence over civil society organisations, mainly those involved in electoral activities (Mozambique Political Process Bulletin, July 2005, p 9), its own pitiful relationship with civil

27 Interview with professor Lourenço do Rosário, Rector of the Polytechnic University and Chairman of the MARP Forum in Mozambique and one of the most senior Frelimo members who is an academic. 
society organisations is partly due to its poor strategic vision, arguably because the most vocal civil society organisations (for example, the Centro de Integridade Publica - CIP; the Observatorio do Meio Rural; the Instituto de Estudos Sociais e Economicos - IESE) are independent organisations which are labelled as proopposition by the government, but Renamo has failed to build on that and establish plausible relationships with them.

For most scholars (De Tollenaere 2013; Forquilha and Orre 2012; Rønning 2010, 2011; Nuvunga \& Mohamed Salih 2010; Pereira 2008) this is an indication of Renamo's failure to make an institutional transformation from a military movement to a political party.

Consequently, in the two decades of Mozambique's democracy Renamo has never abandoned military language. Through its attitude and behaviour, as well as constitutionally, Renamo, as a political organisation, has always had two distinct faces: that of a legal political party with seats in Parliament and a seat on the council of state for the leader of the parliamentary party, but, at the same time, it is an armed group that claims to have hundreds of armed men at its former central military base at Gorongosa Mountain (Sofala province) and which has several times resorted to non-democratic means to achieve its goals.

In the past two years there have been press reports about Renamo attacks on police officers. For instance, on 22 April 2011 there was a clash between the riot police (FIR) and Renamo fighters in Maringwe, which resulted in the death of 13 FIR officers (Da Silva 2011). On 4 April 2013 Renamo attacked a FIR camp in Muxungue, killing four FIR officers. The MDM, in turn, emerged at a time when Renamo's electoral performance was in sharp decline. Its leader, Daviz Simango, inflicted two local election defeats on Frelimo candidates in Beira, the country's second city and the 'capital' of anti-Frelimo sentiment, and in so doing galvanised sympathy among various social groups (Nuvunga \& Adalima 2011; Chichava 2010b).

The MDM's partial exclusion from the 2009 elections agitated the country and generated waves of support within civil society. This gave the impression that the party had strong roots / relations with civil society (Nuvunga \& Mohamed Salih 2010). However, the interviewees suggest that civil society organisations were against the MDM's partial exclusion from the electoral process (Nuvunga \& Mohamed Salih 2010) although people sympathised with the MDM because, in the context of a desire for political change, it had the potential to challenge Frelimo. As the MDM has only participated in one general election it is not yet possible to assess its electoral support, although it did obtain an overwhelming victory in the Quelimane town local elections (see below).

In summary, as a former single party that has been in power since independence, Frelimo has roots in all segments of society in both rural and urban 
areas. However, it is nevertheless interesting that in a country of 10 -million voters it only wins three million votes. This suggests that its roots in society have much to do with the fact that it controls the political economy of the country, which, in the case of Mozambique, means the power to determine 'who gets what' and is less related to party identification on the basis of ideology.

Although Renamo has lost many of its electoral social bases, mainly the traditional authorities, it is still deeply rooted in society, mainly in rural communities. However, as the next section shows, it is approaching institutional and organisational failure, which makes it impossible for it to mobilise its voters. The MDM is growing rapidly. In its first general election, in 2009, it obtained two seats in Parliament, representing Maputo city. No other party in Mozambique has ever done this, which is telling evidence of the growing level of its support.

\section{Organisation}

Frelimo has a long tradition of holding congresses. Since it was founded in 1962 it has held 10 - the tenth being in September 2012. The party spent $\$ 8$-million on the logistics of its tenth congress, for which it built a town. In the Mozambican context Frelimo is a wealthy party. It has a company, SPI-Gestão e Investimentos, Lda, ${ }^{28}$ as its financial arm. Through this company Frelimo controls important economic and financial sectors in the country (Nuvunga \& Hout forthcoming). But it is mainly by controlling the state that Frelimo maintains high levels of wealth (AfriMAP 2009; MARP 2010). The state is clearly at the service of Frelimo (Forquilha \& Orre 2012): many events, from congresses to election activities, take place with the help of state resources (Nuvunga 2012). With the arrival of President Guebuza in the party leadership Frelimo has significantly improved its organisational structure along the lines of democratic centralism. From the grassroots to the top, a cell system ensures that Frelimo is highly organised and hierarchical.

With the support of the United Nations Operations in Mozambique (Onumoz), which, inter alia, had to establish a US\$15-million UN-managed Trust Fund for the transformation of the former guerrilla movement into a political party, Renamo has also built a hierarchically functional party structure, from its headquarters in Maputo to remote villages in the rural areas, mainly benefiting from its massive presence in the rural areas. Moreover, it had strong links with the international community based in Maputo. However, the internal erosion of

28 SPI - Gestão e Investimentos, Lda was created in December 1992. According to the online news service Canal de Moçambique, SPI has 35 entries in the company register and corporate objects that include commerce and industry through direct investment, shareholding management and financial intermediation Canal de Moçambique also reports that SPI has partnerships with groups in Hong Kong, Kuwait, South Africa, Brazil, Portugal, China and Canada. According to the same source, SPI also has partnerships with state companies. 
the party from 2004 onwards, due in part to the authoritarianism of the party leadership (Forquilha \& Orre 2012) and the reduction in funding because of its declining share of seats in Parliament (former Renamo MP) dictated the closure of almost all local party offices, with most of its provincial and district leaders joining the MDM. The only Renamo offices that are active are those in Quelimane, Beira and Nampula, although Renamo flags are still massively visible in the homes of their local leaders in the central and northern provinces of Sofala, Manica, Tete, Zambezia and Nampula.

... there have never been decisions ordering the closure of Renamo provincial and district offices in the country, but in practice many of them are no longer functioning, mainly the ones in the southern region (Gaza, Inhambane, Maputo city and Maputo province). There is a logistical factor, because the reduction of the number of seats in Parliament resulted in a reduction of funds for the maintenance of offices. Therefore members had to look for other alternatives instead of devoting themselves to the party. Membership contributions are not enough to maintain party offices

Senior Renamo MP 2013

Renamo has no tradition of holding party congresses. After several postponements it held its third congress in October 2001 and for the first time it seemed that the party leader was being elected. However, what happened there had nothing to do with what is understood as internal party democracy. Three candidates ran for election: Dhlakama, Manuel Pereira and Agostinho Murrial. Whilst Pereira was best known for his threat to expel the Changana people (originally from the south) from the central and northern regions of the country, he was then not yet one of the party stalwarts. Murrial was unknown to most of the public at large (Lalá \& Ostheimer 2003). This led observers to say that the internal party presidential election was a democratic façade (Senior Renamo MP).

This situation substantiated the suspicion that Dhlakama does not tolerate competition within the party. The expulsion of Raul Domingos in 2000 because of dubious allegations was seen as an indication that Dlhakama wanted to manage the party his way. Many others were expelled from the party after revealing thinking that differed from that of the president (Renamo MP). Lalá \& Ostheimer (2003, p 26), who have worked with Renamo, argue that Renamo's internal party democracy frustrated most of the senior party members, mainly those who thought differently but remained silent, fearing vengeance '... in the long run, this stagnation of the party will cause more people [with political ambitions] to leave the party or it may lead to an internal party uprising'. 
Ten years later, members abandoning the party and expulsions are a key institutional pattern within Renamo. The victims include Daviz Simango (elected mayor of Beira on a Renamo ticket in 2003); Maria Moreno (former head of the Renamo parliamentary group) and two former senior Renamo MPs, Luís Boavida and Manuel de Araújo.

With the exception of Raul Domingos, all these people are potential key MDM leaders. This pattern has weakened Renamo internally and externally. Internally it has destroyed the technical capacity and cohesion to counter overwhelming Frelimo dominance and externally it has enabled the creation of strong breakaway parties - firstly, the Party for Development and Democracy (PDD) and, more recently, the MDM - which have taken away much of Renamo's electoral and popular support, as shown in its dramatic loss of votes.

Without regular congresses important decisions (for example, the replacement of the party's secretary general) are taken at meetings of the political committee. This was the case with the replacement of Viana Magalhaes by Ossufo Momade in 2005 and of Manuel Ossufo by Momade Bissopo at a meeting held on 17 July 2012. In its heyday Renamo tried to institutionalise internal structures in the form of a shadow government, consisting of 15 shadow ministers, but ten years later only the military side, namely defence and security, led by Hermínio Morais, who had been a Renamo general during the civil war, and the ministry for veterans, led by Ossufo Momade, a Renamo veteran of the civil war, are active. The remaining shadow ministries disappeared without delivering anything substantial: '... the very centralised management of the party does not allow other figures to surface ... thus the existence of a Shadow Government does not make any sense because it never holds meeting nor is it referred to,' says Eduardo Namburete, advisor to the Renamo president.

This situation is not new to Renamo. Its political structure during the war was little more than an off-shoot of its military command structure (Vines 1996). It was supposedly formalised as the 'National Council' at Renamo's first Congress in May 1982. This Council was described in September 1982 as an 'Executive Council' comprised of 12 men with specific portfolios. However, it was described in early 1984 as a 'very basic structure' (Vines 1996) in which members did not have portfolios, but were given specific tasks by the president from time to time.

The post of general secretary was abolished at the party's second congress, in 1989, with its functions absorbed into the previously unknown presidential cabinet. In March 1983 another Renamo structure was set up following a meeting held in Geneva. This was the 'government in exile', otherwise called the 'shadow cabinet'. This structure was said to be distinct from the National Council (Vines 1996) but appears to have had little impact as it was never heard, even during the peace talks in Rome. This depiction suggests a continual moving of the goalposts, 
the abolition and creation of new ones, changes in the composition, and so on. While there is nothing wrong with innovating organisational structures, the more it happens the more it appears to suggest a lack of organisational consistency.

Organisationally, Renamo is nearing paralysis. At the end of 2011 Afonso Dhlakama left the capital, Maputo, going firstly to Nampula and more recently returning to Renamo's old main military base at Gorongosa Mountain, from where he calls for direct negotiations with the government for power sharing, ignoring the party's representation in Parliament. While Dhlakama claims to be in full control of the party, recent public statements of high ranking party leaders reveal that his authority is systematically disregarded in key party decisions, with the military wing prevailing over the party leader. An example is Dhlakama's return to Gorongosa. In an interview, Herminio Morais said the decision that Dhlakama should return to Gorongosa was a military, not a political one (Canal de Moçambique October 2012).

In another interview, Ossufo Momade stated that '... Renamo's glorious military force will attack the capital city Maputo without authorisation of its leader, Dhlakama' (Renamo 2013). While this may be a political and tactical strategy, it is a politically and structurally bizarre statement as it reveals a lack of internal cohesion.

In 2005 and 2009 Renamo MPs publicly flouted Dhlakama's authority when they took up their seats in Parliament, despite his public decision to boycott parliamentary activity, alleging electoral fraud. While Dhlakama intended to show he had control over the party he shocked the public when, at a press conference in Gorongosa, he claimed to have ordered an attack on the FIR camp that had killed four policemen on 4 April 2013.

Renamo is failing to live up to one of the key elements of the notion of a political party: contestation of elections. It has either boycotted or failed to put up candidates in recent elections. After boycotting the first local government elections in 1998, it also boycotted the by-elections in Pemba, Quelimane and Cuamba in 2011 and the by-election in Inhambane in 2012. It has also declined to take up its seats on the National Electoral Commission because of its objections to the results of the 2013 local government elections.

The MDM held its first congress in December 2012. It was well organised, with delegates coming from across the country in an attempt to show that the party is national not regional. Although there was only one candidate for party president, with the incumbent standing unopposed, the party held an election for its leaders, which could establish a precedent. However, the extent of internal democracy is still to be demonstrated because, as recently as 2010, its leader, Daviz Simango, usurped the powers of the congress when he dissolved the party's political commission on the grounds that he wanted to instil new dynamism in 
the way the party worked, although the real objective was '... to remove Ivete Fernandes [a former Renamo general secretary who left the party to participate in the formation of the MDM] ...' (Chichava 2010a, p 19). At the time it was felt that Simango was using the same methods as Dhlakama.

Recent developments within the MDM following its first congress suggest a rapidly growing organisational structure. The president is at the centre of power, but both the secretary general and the provincial delegates have formal positions and power. It has operational offices all over the country and holds regular press conferences. Its actions conform to the Constitution and ordinary laws, even when faced with extreme cases of political intolerance, apparently on the part of Frelimo members, such as setting fire to its offices and partisan behaviour of state institutions, including the police. For instance, after the 2012 by-elections in Inhambane MDM members were charged with political disorder and sentenced to a year in jail. Since the accused were not present at the trial the MDM, instead of hiding its members, handed them over to the court to be imprisoned.

\section{Autonomy}

Frelimo has had three changes of leadership in its history, but the most significant in terms of the institutionalisation of the party occurred in 2005, when Joaquim Chissano stood down and Armando Guebuza became the party leader. The significance is that the other changes followed the death of an incumbent leader so this was the first democratic leadership change within the party.

Renamo was created by André Matsangaiça as a guerrilla movement, fighting the Frelimo government. Matsangaiça died in combat in the early 1980s and, following his death, Afonso Dhlakama took over. In 1992, after the peace agreement was signed, Dhlakama turned Renamo into a political party. Since then there have no changes in its leadership.

After the leadership change Frelimo substantially increased its percentage of electoral support albeit with a small absolute decline in the 2004 elections (see Figure 1). In 2009 Frelimo received three million votes. All respondents expressed the opinion that the party had shown marked improvements in its organisation in terms of democratic centralism following the rise to power of President Guebuza, giving examples of such internal procedures as internal elections serving the interests of the leadership.

Former freedom fighters have veto power within the party, but the leadership has decision-making autonomy. By contrast, Dhlakama, with his authoritarian style, has shown that the party is as he conceived it, but he is increasingly losing power to Renamo's growing military arm. The MDM has received considerable support from the so-called donor community based in Maputo, although they have never interfered in party affairs (Nuvunga \& Adalima 2011). 
The independent media, mainly the Mozambique Political Process Bulletin, have, since the first democratic elections, documented several instances of electoral intimidation by both Frelimo and Renamo social organisations and supporters, but increasingly by Frelimo social groups and supporters (Nuvunga 2012).

Renamo is best known to most of the world for its grotesque campaign of terror against Mozambican civilians (Manning 1998), for its status as an army of captives, and of guerrillas-turned-party-members. It carries the stigma of the massacre of innocent people, of thwarting the consolidation of independence, of destruction of economic and social infrastructure throughout the civil war and the fact that to this day its leaders are members of the former rebel group (MARP 2010). However, it is still well regarded in the central region of the country, where it originated, with its roots in the representation of anti-Frelimo sentiment (Lundin 1995; Brito 1995; Manning 1998; Tollenaere 2004; Nuvunga 2005; Carbone 2005).

However, although Renamo projects itself as the party that fought for democracy, thus claiming the fatherhood of democracy, the loss by 1999 of the territories it controlled, the emergence of the MDM - as a breakaway from Renamo - and the recent militarisation of the party have eroded much of its popular support, as shown clearly by its loss of votes and its political isolation. So, while Frelimo tends to attract supporters in urban areas and in the provinces in the north (Niassa and Cabo Delgado) and south (Inhambane, Gaza and Maputo), Renamo's dwindling popular support is related to regional politics and the areas it controlled as a result of the civil war. The burgeoning MDM is expanding its party activity nationwide, but it was originally a Beira phenomenon (Nuvunga \& Adalima 2011).

\section{Coherence}

The proportional electoral system, based on closed lists, gives primacy to political parties over members of Parliament as individuals (Nuvunga 2005; Sitoe, Matsimbe \& Pereira 2005; Brito 2009). Parliamentary candidates are more concerned about pleasing party leaders than potential voters. This is reflected in the behaviour of members of Parliament who remain faithful to the party in the name of party discipline. The problem is exacerbated by the internal regulations of the Assembly of the Republic, whereby floor crossing is punished by losing one's seat. In order to remain in Parliament the member who abandons his/her party must not join another party. This results in a high degree of coherence on the parliamentary benches, albeit with more discipline in Frelimo as it controls the country's political economy.

Mozambican political parties never admit to the existence of internal factions. Following the departure of Joaquim Chissano and the arrival of Armando Guebuza 
it was clear that there were at least two factions within Frelimo, but these were never acknowledged publicly. There were instances of tension within Frelimo that gave the impression that there could be a political break, but it all ended well and the tenth congress demonstrated party cohesion. This can be explained by the fact that there are no opportunities to accumulate wealth outside the party, or even to defend wealth already acquired. So it is in everyone's interest to maintain party cohesion at all costs.

Frelimo uses its control of the economy and international employment to accommodate the various groups and thus dissipate internal tensions (MARP 2010). Renamo and the MDM do not have this facility and, in a context where the only source of revenue is the state funding for parties with parliamentary seats and the only source of patronage is the eligible places in lists for Parliament, this triggers internal conflicts in the form of disputes over scarce resources.

Dissidence and expulsions marked the formation of Frelimo. There was no tolerance in these processes, which, in some cases, culminated in the loss of lives (Nuvunga \& Adalima 2011). But in the multiparty context Frelimo has accepted and lives with political parties formed by former dissidents. As observed above, recent history has shown that no-one leaves Frelimo. Intolerance and power struggles led to two party-shaking expulsions from Renamo, those of Raul Domingos and Daviz Simango, which produced two opposition parties, namely the PDD and the MDM. Renamo does not accept invitations to attend ceremonies held by other parties and does not participate in public state ceremonies, claiming that they are partisan events. In Renamo's language members of the other parties are 'thieves' (Frelimo) and 'traitors' (MDM) (Renamo 2013). The MDM's relationship with the other parties has, thus far, been cordial, for example, it invited and welcomed Frelimo party members to its first congress, held in Beira.

\section{CONCLUSION}

This article has probed party institutionalisation in Mozambique. Its starting points were, on the one hand, the theoretical understanding that the institutionalisation of parties is fundamental for them to perform citizen-related roles and provide effective opposition, the primary contribution parties can make to democratic consolidation. On the other hand, it demonstrated emperically that African political parties are plagued by weak organisation and weak links with the society they are supposed to represent. The article found that the notion of 'political party' is something new in Mozambique, with the first party arising from the transformation of FRELIMO, the former liberation movement, into a political party.

The second wave of party formation was enabled by the constitutional reform in the wake of the democratisation process that arrived on the African 
continent in the early 1990s, giving birth to myriad political parties, including the transformed former rebel movement.

The article also argues that the landscape of the effective parties shows a highly institutionalised Frelimo; a collapsing Renamo, after 10 years of considerable institutionalisation; and an institutionalising MDM. Although Frelimo performs well at all levels of party institutionalisation, it is much more highly regarded as a solidly organised party. It is coherent and has deep roots in society, but it is not yet clear to what extent these roots would resist the test of a term in opposition, arguably because they are dependent on Frelimo commanding the heights and on the fact that it has the state machinery at its service. Renamo, once a serious contender for political power, has collapsed in organisational terms, but keeps considerable roots in society, in the rural areas of the central provinces of the country. Nevertheless, it is incoherent. The MDM has proven to have strong organisational leadership and signs of considerable roots in society.

Finally, the article concludes that although the opposition parties are partly to blame for their misfortunes, the nature of Frelimo's relations with society bears the main responsibility for the impoverishment of the opposition. Shaped by its victory in the 10-year liberation struggle and, in particular, by the proclamation of independence in 1975; moulded in the context of liberating the 'land' and 'the people' from colonial rule; commanding the heights of the political economy, enabled by economic liberalisation and politically controlled privatisation and having recaptured the state due to democratisation from above, Frelimo's relationship with society makes it difficult for newcomers to break in and challenge its control over the state.

Frelimo has difficulty accepting that other political groups can mobilise support among 'the people' and on the 'land' it liberated from colonial rule. Hence its efforts to thwart the ascendency of the opposition - mainly Renamo, but lately also the MDM. So its relationship with society makes it difficult for the opposition parties to develop. 


\section{- REFERENCES}

Adalima, J. 2009. ‘Espaços criados ou inventados? Uma análise da participação em Moçambique'. Economia, Politica e Desenvolvimento 1(1).

AfriMAP. 2009. Mozambique: Democracy and Political Participation. Open Society Institute, South Africa.

Basedau, M \& A Stroh. 2008. 'Measuring Party Institutionalisation in Developing Countries: A New Research Instrument Applied to 28 African Political Parties. GIGA Working Articles Series 68.

Bogaards, M. 2000. 'Crafting Competitive Party Systems: Electoral Laws and the Opposition in Africa'. Democratisation 7(4).

Bogaards, M. 2004. 'Counting Parties and Identifying Dominant Party Systems in Africa'. European Journal of Political Research 43.

Bowen, M L. 1992. 'Beyond Reform: Adjustment and Political Power in Contemporary Mozambique'. The Journal of Modern African Studies 30(2).

Brito, L. 1988. 'Une relecture necessaire: la genese du parti-Etat Frelimo'. Politique Africaine 29.

Brito, L. 1995. 'O Comportamento eleitoral nas primeiras eleições multipartidárias em Moçambique'. In M B Eleições (ed). Democracia e Desenvolvimento. Maputo: Embaixada do Reino dos Países Baixos.

Brito, L. 2009. 'OSistema Eleitoral: Uma Dimensão Critica da Representação Política em Moçambique'. In L Brito, C N Castel-Branco, S Chichava \& A Francisco (eds). Desafios para Moçambique 2010. Maputo: IESE.

Burnell, P. 2004. Building Better Democracies: Why Political Parties Matter. London: Westminster Foundation for Democracy.

Canal de Moçambique, 31 October 2012

Carbone, G M. 2005. 'Continuidade na renovação? Ten years of multiparty politics in Mozambique: Roots, evolution and stabilisation of the Frelimo-Renamo party system'. Journal of Modern African Studies 43(3).

Carbone, G. 2007. 'Political Parties and Party Systems in Africa: Themes and Research Perspectives'. World Political Science Review 3(3).

Chichava, S. 2010a. Movimento Democrático de Moçambique: uma nova força politica na democracia moçambicana? Maputo: Cadernos IESE $n^{\circ} 2$.

Chichava, S. 2010b. 'For a socio-historical understanding of ethnicity in Mozambique'. Paisagem da Democracia 1. Maputo: NIMD Moçambique.

Crotty, W. 1993. 'Notes on the study of political parties in the third world'. American Review of Politics 14.

Da Silva, A. 2011. 'At least 13 FIR agents may have died in Marínguè'. Canal de Moçambique ed. Available at: macua.blogs.com/moambique_para_ todos / 2011/05/ relatos-dos-confrontos-com-homens-da-renamo.html?cid $=6 \mathrm{a} 00 \mathrm{~d} 83451 \mathrm{e} 35069 \mathrm{e} 201538 \mathrm{e} 6 \mathrm{dbe} 6 \mathrm{~b} 970 \mathrm{~b}$

De Renzio, P \& J Hanlon. 2009. 'Mozambique: Contested Sovereignty? The Dilemmas of Aid Dependence'. In L Whitfield (ed). The Politics of Aid: African 
Strategies for Dealing with Donors. Oxford: Oxford University Press.

Della Rocca, R M. 1998. Mozambique: Da Guerra à Paz. História de uma Mediação Insólita. Maputo: Livraria Universitária, Universidade Eduardo Mondlane.

De Tollenaere, M. 2004. 'Democracy and Elections in Mozambique: Theory and

Practice'. In B Mazula (ed). Mozambique: Ten Years of Peace. Maputo: Centro de Estudos de Democracia e Desenvolvimento.

Diamond, L. 1994. Political Culture E Democracy in Developing Countries. London: Lynne Rienner Publishers.

Diamond, L \& M F Plattner (eds). 1999. Democratisation in Africa. Baltimore, Md: Johns Hopkins University Press.

Dos Santos, M. STV, May 2005

Dos Santos, M. Noticias, 19 June 2007.

Duverger, M. 1985. Os Grandes Sistemas Políticos, Instituições Políticas e Direito Constitucional. Coimbra: Almeida.

Erdmann, G \& M Basedau. 2007. 'Problems of Categorizing and Explaining Party

Systems in Africa’. Working Articles. Hamburg: German Institute of Global and Area Studies.

Forquilha, S C. 2006. 'Des "autoridades gentílicas" aux "autoridades comunitárias".

Le processus de mobilisation de la chefferie comme ressource politique.

Etat, chefferie et démocratisation au Mozambique. Le cas du district de

Cheringoma'. Doctoral thesis, Bordeaux: Université de Bordeaux.

Forquilha, S C. 2009. 'Governação Distrital no Contexto das Reformas de

Descentralização em Moçambique: Logicas, Dinâmicas e Desafios'. In L Brito,

C N Castel-Branco, S Chichava \& A Francisco (eds). Desafios para Moçambique 2010. Maputo: IESE.

Forquilha, S C \& A J Orre. 2012. ‘Conselhos Locais e Institucionalização Democrática em Moçambique'. In B Weimer (ed). Moçambique: Descentralizar o Centralismo - Economia politica, recursos, resultados. Maputo: IESE.

Guiliche, J M. 2011. 'Governação Eleitoral e Democratização em Moçambique:

Análise do Desempenho da CNE na Supervisão das Eleicoes (1999-2004)'.

BA Hons dissertation, Political Science, Universidade Eduardo Mondlane.

Haggard, S \& R Kaufman. 1995. The Political Economy of Democratic Transitions.

New Jersey: Princeton University Press.

Hanlon, J. 2012. MOZAMBIQUE 202 - news reports \& clippings, 1-8 October.

Heywood, A. 2002. Politics. London: Palgrave.

Huntington, S P. 1968. Political Order in Changing Societies. New Haven: Yale University Press.

Joseph, R. 1999. 'Africa, 1990 - 1997: From Abertura to Closure'. In L Diamond \& M F Plattner (eds). Democratisation in Africa. Baltimore, Md: Johns Hopkins University Press.

Jossias, E. 2007. 'Entre a Colónia e a Nação: moçambicanos deficientes físicos das forças armadas portuguesas', Master's Dissertation, Lisbon.

Kadima, D \& Z Matsimbe. 2006. 'Renamo União Eleitoral: Understanding the 
Longevity and Challenges of an Opposition Party Coalition in Mozambique'. In D Kadima (ed). The Politics of Party Coalitions in Africa. Johannesburg: EISA and Konrad-Adenauer-Stiftung.

Kopecký, P \& P Mair. 2003. 'Political Parties and Government'. In M A Mohamed Salih (ed). African Political Parties: Evolution, Institutionalism and Governance. London: Pluto Press.

Kuenzi, M \& G Lambright. 2001. 'Party System Institutionalisation in 30 African Countries'. Party Politics 7(4).

Kuenzi, M \& G Lambright. 2005. ‘Party Systems and Democratic Consolidation in Africa's Electoral Regimes'. Party Politics 11(4).

Laakso, M \& R Taagepera. 1979. 'Effective' Number of Parties: A Measure with Application to West Europe'. Comparative Political Studies 12.

Lala, A \& A E Ostheimer. 2003. Como limpar as nódoas do processo democrático: Os desafios da transição e democratização em Moçambique (1990-2003). Maputo: Konrad-Adenauer-Stiftung.

LaPalombara, J \& M Weiner. 1996. 'The Origin and Development of Political Parties'. In J LaPalombara \& M Weiner (eds). Political Parties and Political Development. Princeton: Princeton University Press.

Lindberg, S. 2007. 'Institutionalisation of Party Systems? Stability and Fluidity Among Legislative Parties in Africa's Democracies'. Government and Opposition 42(2).

Lipset, S M. 2000. 'The Indispensability of Political Parties'. Journal of Democracy $1(11)$.

Lundin, I B. 1995. ‘Partidos Políticos: a leitura da vertente etnico regional do processo democrático'. In B Mazula. Eleições, Democracia e Desenvolvimento. Maputo: Embaixada do Reino dos Países Baixos.

Mainwaring, S., G O’Donnell \& J S Valenzuela (eds). 1992. Issues in Democratic Consolidation: The New South American Democracies in Comparative Perspectives. Notre Dame, In: University of Notre Dame Press.

Mair, P. 2007. 'Party Systems and Alternation in Government, 1950-200: Innovation and Institutionalisation'. In S Gloppen \& L Raker (eds). Globalisation and Democratisation: Challenges for Political Parties. Bergen: Fagbokforlaget.

Manning, C. 1998. 'Constructing Opposition in Mozambique: Renamo as Political Party'. Journal of Southern African Studies 24(1).

Manning, C. 2005. 'Assessing African Party Systems after the Third Wave'. Party Politics 11(6).

Mecanismo Africa de Revisão de Pares (MARP). 2010. ‘República de Moçambique: Relatório de Revisão do País', July.

Mazula, B. 1995. 'As Eleicoes Mocambicanas: Uma Trajectoria da Paz e da Democracia'. In B Mazula (ed). Moçambique: Eleições, Democracia e Desenvolvimento. Maputo: Inter-Africa Group.

Meleshevich, A. 2007: Party Systems in Post-Soviet Countries: A Comparative Study of Political Institutionalisation in the Baltic States, Russia, and Ukraine. New York: Palgrave. 
Mohamed Salih, M A. 2001. African Democracies \& African Politics. London: Pluto Press.

Mohamed Salih, M A. 2003. African Political Parties: Evolution, Institutionalism and Governance. London: Pluto Press.

Monga, C. 1999. 'Eight problems with African politics'. In L Diamond \& M F Plattner (eds). Democratisation in Africa. Baltimore, Md: Johns Hopkins University Press.

Moreira, A. 2001. Ciência Politica. Lisboa: Almedina.

Mozaffar, S \& J Scarritt. 2005. 'The puzzle of African party systems'. Party Politics 11(4).

Mozambique Peace Process Bulletin 6, October 1993.

Mozambique Political Process Bulletin 1, January 2003.

Mozambique Political Process Bulletin 2, March 2003.

Mozambique Political Process Bulletin 29, 15 July 2005.

Newitt, M. 1995. A History of Mozambique. Indiana: Indiana University Press.

Nuvunga, A. 2005. Multiparty Democracy in Mozambique: Strengths, Weaknesses and Challenges. EISA Report No 14.

Nuvunga, A. 2007. Post-war Reconstruction in Mozambique: The UN's Trust Fund. London: TIRI.

Nuvunga, A. 2012. 'Tendências nas Eleições Municipais de 1998, 2003 e 2008'. In B Weimer, (ed). Moçambique: Descentralizar o Centralismo - Economia politica, recursos, resultados. Maputo: IESE

Nuvunga, A \& J Adalima. 2011. 'Mozambique Democratic Movement (MDM): An analysis of a new opposition party in Mozambique'. Studies on Political Parties and Democracy. Maputo: Friedrich Ebert Foundation.

Nuvunga, A \& W Hout. Forthcoming. 'Mozambican Multiparty Politics and the Market Economy: Assessing the Role of Frelimo'. Submitted to The Journal of Modern African Studies.

Nuvunga, A\& M A Mohamed Salih. 2010. 'Mozambique's 2009 Elections: Framing Democratic Consolidation in Context'. Journal of African Elections 9(1).

Nuvunga, A. \& M A Mohamed Salih. Forthcoming. 'Party Dominance, Electoral Instruments and Institutions: Framing Frelimo's Dominance in the Context of Electoral Governance'. Submitted to Africa Review.

Nwokedi, E. 1995. Politics of Democratisation: Changing Authoritarian Regimes in Sub-Saharan Africa. Hamburg: Demokratie und Entwicklung.

Pereira, J G. 2008. 'Antes o "diabo" conhecido do que um "anjo" desconhecido': as limitações do voto económico na reeleição do partido FRELIMO. Análise Social XLIII (2).

Pitcher, M A. 1996. 'Recreating Colonialism or Reconstructing the State? Privatisation and Politics in Mozambique'. Journal of Southern African Studies 22(1).

Rakner, L \& N van de Walle. 2007. 'Opposition Parties in Sub-Saharan Africa'. Working Parties Series No 12-07. Centre for International Studies. 
Randall, V (ed). 1988. Political Parties in the Third World. London: Sage Publications. Randall, V. 2006. 'Party Institutionalisation and its Implications for Democracy'. Article for Session MT 07.239 Political Parties and Democratisation, IPSA Congress, Fukuoka, July 9-13.

Randall, V. 2008. Case Study One: Political Parties, Their Social Ties and Role in Political Change. Oxford University Press.

Randall, V \& L Svåsand. 2002. 'Party Institutionalisation in New Democracies'. Party Politics 8(1).

RENAMO. 2013. Available at: www.renamo.org.mz/index.php/o-presidente/80news / 168-conferencia-de-imprensa-sobre-a-posicao-da-renamo-14-03-13

Rønning, H. 2010. Democracies, Autocracies or Partocracies? Reflections on what happened when Liberation Movements were transformed to Ruling Parties, and Pro-Democracy Movements Conquered Government. Maputo: CMI and IESE.

Rønning, H. 2011. 'The FRELIMO State'. Conference organised by the Department of Political Science \& Public Administration, Makerere University, Uganda, and the Christian Michelsen Institute (CMI), Norway, on Legitimacy of Power - Possibilities of Opposition, 30 May-1 June, Jinja, Uganda.

Rosário, D M. 2012 'Alternância eleitoral do poder local - os limites da descentralização democrática: O Caso do Município da Ilha de Moçambique, 20032008'. In B Weimer (ed). Moçambique: Descentralizar o Centralismo - Economia politica, recursos, resultados. Maputo: IESE.

Sanches, E R. 2010. 'The dynamics of party competition in Africa: A theoretical approach'. ECPR Graduate Conference, Dublin, 31 August-1 September.

Sartori, G. 1976. Parties and Party Systems: A Framework for Analysis. Cambridge: Polity Press.

Serra, A M de Almeida. 1993. Moçambique: da Independência à actualidade. Evolução económica e social, 1975-90. Lisboa: Centro de Estudos sobre África e do Desenvolvimento

Simutanyi, N. 2009. 'Impact of Breakaway Groups on Parties and Political Systems: Recent Development in Southern Africa'. Article prepared and presented to the Frelimo Party School and Friedrich Ebert Stiftung Policy Forum on the 'Impact of Breakaway Groups on Parties and Political Systems: Analyzing Root Causes - facing a Democratic Challenge', Hotel Avenida, Maputo, 17-19 May.

Sitoe, E, Z Matsimbe \& A Pereira. 2005. Parties and Political Development in Mozambique. EISA Research Report No 22.

Sitoe, E J. 2004. 'Making Sense of the Political Transformations in Angola and Mozambique from 1984 to 1994'. PhD thesis, Essex University, UK.

Sitoe, E J. 2011. Post-Colonial Political Transformations in Angola and Mozambique: Dynamics of the Processes of Democratisation Taking Place from 1984 to 1994. Saarbrücken, Germany: Lambert Academic Publishing, GmbH \& Co.

Sitoe, Eduardo J. Forthcoming. 'State \& Society: Structure \& Process of Governance in Mozambique'. African Governance Report III, AGRIII - Elections and Diversity Management. 
Smith, B C. 2009. Understanding Third World Politics: Theories of Political Change and Development. Hampshire, UK: Palgrave Macmillan.

Sumich, J \& J Honwana. 2007. Strong Party, Weak State: Frelimo and State Survival Through the Mozambican Civil War: An analytical narrative on State-Making. London: Crisis States Working Papers Series No 2.

Van de Walle, N \& K S Butler. 1999. 'Political parties and party systems in Africa's illiberal democracies'. Cambridge Review of International Studies 13(1).

Van Cranenburgh, O \& P Kopecky. 2004. Political Institutions in New Democracies: (Not so) Hidden Majoritarianism in Post-apartheid South Africa. Leiden: Palgrave Macmillan Lda.

Vines, A. 1996. RENAMO: From Terrorism to Democracy in Mozambique? Centre for Southern African Studies, University of York.

\section{Interviews}

Professor Lourenço do Rosário, Rector of the Polytechnic University and Chairman of the MARP Forum in Mozambique and one of the most senior Frelimo members who is an academic.

João Ulrich, director of an international organisation that worked closely with Renamo for more than 10 years.

Senior Renamo MP and a previous Renamo general secretary, 10 April 2013. The MP requested anonymity.

Former Renamo MP who requested anonymity. 